\title{
A ESTÉTICA NEGRA DE ZÓZIMO BULBUL EM CENA:i NOVAS POSSIBILIDADES PARA PENSAR CINEMA, CURRÍCULO E FORMAÇÃO DE PROFESSORES
}

\author{
THE BLACK AESTHETICS OF ZÓZIMO BULBUL IN SCENE: \\ NEWS POSSIBILITIES TO THINK CINEMA, CURRICULUM AND \\ TEACHER EDUCATION
}

\section{LA ESTÉTICA NEGRA DE ZÓZIMO BULBUL EN EL ESCENARIO: NUEVAS POSSIBILIDADES PARA PENSAR CINE, PLAN DE ESTUDIOS E FORMACIÓN DE PROFESORES}

Fábio José Paz da Rosa ${ }^{1}$

Adriana Mabel Fresquet ${ }^{2}$

\begin{abstract}
RESUMO
Neste ensaio analisa-se a cinematografia negra de Zózimo Bulbul enquanto possibilidade de educação etnorracial na formação de professores. Para isso, o presente trabalho, em um primeiro momento, contextualiza brevemente a trajetória educacional e artística desse cineasta com o intuito de compreender seu pensamento e de verificar como, no futuro, ele se evidenciaria por meio do cinema. Em um segundo momento, relaciona-se as questões sobre o cinema de Bulbul, currículo e negritudes em uma perspectiva multi e intercultural na formação de professores. Por último, tais temáticas são inter-relacionadas quando se propõe uma análise fílmica deAlma no Olho (1974), primeiro curta-metragem produzido por Zózimo, em que conhecimentos e saberes são produzidos entre realidade e ficção, entre estranhamentos e emancipações dos sujeitos espectadores.
\end{abstract}

PALAVRAS-CHAVE: Cinema negro. Formação de professores. Zózimo Bulbul.

\section{ABSTRACT}

This essay analyzes the black cinematography of Zózimo Bulbul as a possibility of Ethno-racial Education in Teacher Education. For this, the present work, in a first moment, briefly contextualizes the educational and artistic trajectory of this filmmaker with the intention to understand his thought and to verify how, in the future, he would was be evidenced through the cinema. In a second moment, the questions about the cinema of Bulbul, curriculum and blackness in a multi and intercultural perspective in the formation of teachers. Finally, such themes are interrelated when is proposed a film analysis of Alma in the Eye (1974), the first short film produced by Zózimo, in which knowledge and knowledge are produced between reality and fiction, between estrangement and emancipation of spectator subjects.

KEYWORDS: Black cinema. Teacher Education. Zózimo Bulbul.

\footnotetext{
${ }^{1}$ Doutorando em Educação -Universidade Federal do Rio de Janeiro (UFRJ) - Rio de Janeiro, RJ - Brasil. Docente do curso de Pedagogia e da Especialização em Psicopedagogia Clínica e Institucional pela Universidade Estácio de Sá (ESTACIO)- Rio de Janeiro, RJ - Brasil. E-mail:fabiojp83@yahoo.com.br.

${ }^{2}$ Doutora em Ciências Psicopedagógicas - Pontifícia Universidad Católica Argentina (UCA), Buenos Aires Argentina.Professora associada da Faculdade de Educação da Universidade Federal do Rio de Janeiro (UFRJ) Rio de Janeiro, RJ - Brasil. E-mail:adrianafresquet@gmail.com.
} 


\title{
RESUMEN
}

En este ensayo se analiza la cinematografía negra de Zózimo Bulbul como una posibilidad para la educación etnorracial en la formación docente. Para ello, en este documento, en un primer momento, se contextualiza brevemente la trayectoria educativa y artística de este cineasta con el fin de entender su forma de pensar y de ver cómo, en el futuro, lo demostraría a través de las películas. En una segunda etapa, se refiere a las preguntas sobre el cine de Bulbul, su plan de estudios y las negritudes, en una perspectiva multi e intercultural en la formación del profesorado. Por último, estos temas están relacionados entre sí cuando se propone un análisis fílmico de Alma en el ojo (1974), primer cortometraje producido por Zósimo, en el que conocimientos y saberes son producidos entre la realidad y la ficción, entre la extrañeza y la emancipación de los sujetos espectadores.

PALABRAS CLAVES: Cine negro. Formación de Profesores. Zózimo Bulbul.

\section{INTRODUÇÃO À ESTÉTICA DE ZÓZIMO BULBUL}

\author{
"Os professores eram muito despreparados, mas nós \\ começamos a fazer um tipo de jogo com eles. Era juntar \\ grupos que queriam estudar e ultrapassar o tal \\ currículo..." (Zózimo Bulbul)
}

A citação em epígrafe faz parte das memórias do cineasta negro Zózimo Bulbul, publicadasno livro "Zózimo Bulbul: uma alma carioca", em 2014, um ano após sua morte. Nessa obra pode-se perceber que os questionamentos dele em relação às questões raciais e o seu desenvolvimento intelectual para construir novas possibilidades estéticas do negro começam bem antes de suas produções, em meados da década de 1970. Iniciam-se na escola. O cineasta lembra do primeiro contato com o preconceito racial e de como essa questão afetou sua memória para uma cinematografia política que possibilitasse outras imagens para o negro:

O Getúlio Vargas tinha montado a Escola Pública. A escola foi um susto. Eu queria entrar para a escola e quando finalmente entrei deparei, realmente, com o racismo da coisa. Lembro-me dessa professora, a primeira professora do primário. Ela selecionava na sala de aula. As crianças brancas sentavam na frente, as mulatas no meio e as negras atrás (BULBUL, 2014, p.8).

Por meio dos primeiros contatos com o racismo, o futuro cineasta se rebelou contra um sistema escolar que negava sua negritude. Ainda durante a adolescência foi expulso de várias instituições de ensino e, na última vez, foi encaminhado a um reformatório para menores. Lá, além de se contrapor às atitudes dos dirigentes, Bulbul organizava grupos de estudos e, ao mesmo tempo, criticava o material didático. Questionava junto aos colegas a limitação dos docentes que muitas vezes reproduziam um conhecimento estático que deixava à margem a cultura afro-brasileira. 
Zózimo iniciou seus estudos na Escola de Belas Artes, com intuito de se tornar pintor e de trabalhar com arte decorativa.Nessa época, lia sobre as artes indiana, chinesa, africana. Ao ler mais, questionava a escola, o currículo e o despreparo dos professores, incapazesdecorresponder aos anseios de conhecimento de jovens brasileiros dos anos60 do século XX, os quais não se viam representados no conteúdo do currículo escolar.

A trajetória de Zózimo serviu não apenas para uma conscientização das questões raciais, mas também para pensar e construir novas imagens negras pela cinematografia. Apreendemos do pensamento desse cineasta que,por ele haver conquistado um patamar de cultura, sentia-seinconformado mediante a idealização dos conhecimentos.No entanto, apesar de toda sua crítica ao sistema escolar, o cineasta problematiza todas essas questões a partir das suas experiências com as instituições de ensino pelas quais passou. Zózimo viveu esseparadoxo: desejava o conhecimento formal e, ao mesmo tempo, o criticava por não se ver constituído nessa instituição que, mesmo assim, é tão valorizada em suas memórias.

O cinema de Bulbul também se inicia por essa experimentação de trazer à tona os saberes que o constituíam enquanto negro- aos quais ele não teve acesso em sua infância e adolescência - e que agora se tornavam acessíveis. A pujança da revolta contra o preconceito se torna em criatividade que, do mesmo modo, incomoda e sensibiliza, quando os saberes das negritudes invadem o pensamento das imagens desse artista com novas formas de ser e de ver as negritudes.

Com relação às questões da produção imagética dos negros, as críticas e a importância dada ao currículo e à formação dos professores continuam presentes até hoje. Como pensar um currículo em que se consiga não apenas inserir os negros, de modo que atenda aos interesses de parte da mídia, mas quetambém preze pelos saberes desses que compõem - segundo dados do censo de 2013 do Instituto Brasileiro de Geografia e Estatística (IBGE) -o cinquenta e um por cento da população brasileira?

Nesse sentido, concordamos com Bulbul que a escola deve proporcionar uma formação integral e plural que possibilite outros olhares, outros saberes. Se for necessário que se criem espaços para a exibição de filmes, é preciso pensá-los não somente como recursos, mas como arte, etambém como lugar produtor de múltiplos conhecimentos para formar professores com essa perspectiva. Porque, como aponta Fresquet, 
Ver cinema e fazer experiências dessa arte renova, no aprendizado, a vitalidade do aprender, como ação e movimento. Faz parte do aprendizado dessa arte, descobrir aquilo que o cinema mostra e oculta e, nesse exercício do olhar e de escutar, desvendamos mais uma pista fundamental para a educação, que consiste em restaurar o mistério, como elemento intrínseco da construção do conhecimento em um determinado espaço e tempo (FRESQUET, 2013, p.123).

Possibilitar a elaboração de um conhecimento cinematográfico pela sensibilidade e pela estética é potencializar alunos e alunas a se reconhecerem para a compreensão das relações de poder que determinam modos de ver e maneiras de se ver no cinema. Pensando sobre essa questão, quando inicia sua carreira como ator, e posteriormente como diretor e produtor, Zózimo teve que ultrapassar conhecimentos, até então institucionalizados, para construir um caminho próprio. Mas é interessante notar que o cineasta não renega os conhecimentos adquiridos, e até mesmo os utiliza para repensar a produção de novas imagens do negro por meio da arte do cinema. Eis o cerne do ensinamento de Bulbul: questionar e reinventar o conhecimento a partir dos modelos daqueles que detêm o poder econômico e político para, assim, criar novos olhares a partir de um mesmo objeto. Nesse ponto, a cinematografia de Bulbul dialoga com o pensamento de Jacques Rancière acercado regime estético das artes, que "não opõe o antigo e o moderno. Opõe, mais profundamente, dois regimes de historicidade" (RANCIÈRE, 2009, p.35).

Primeiramente, para entendermos como Zózimo fazia cinema idealizando novas imagens do negro, lutando para inserir, nas palavras de Rancière, "a parte não-artística das obras" (2009, p.36), é preciso entender o seu posicionamento político. Paralelamente ao curso na Escola de Belas Artes, o futuro cineasta começou a fazer teatro no Centro Popular de Cultura, que era um órgão ligado à União Nacional de Estudantes (UNE),cujo intuito era fazer pequenas e rápidas apresentações de conscientização para a classe operária. Esse grupamento social já era o público-alvo, pois "a maioria era negra" (BULBUL, 2014, p.18). Após seu exílio durante o período dogoverno militar, ele se junta ao Movimento Negro e,com outros artistas e intelectuais negros,idealiza a Associação Cultural de Apoio às Artes Negras (ACAAN).

Ao participar ativamente de organizações que lutavam pelas questões dos negros, Zózimo entendia que a sua principal causa política tinha uma ampliação quando produzia filmes. Dessa forma, para ele, o cinema só teria sentido pela via política da denúncia contra o racismo. Porém, o mais interessante nesse processo de criação é que o desenvolvimento dessa perspectiva se dava de modo em que se relacionavam passado e presente, possibilidades de liberdade e memória da opressão. Tais questões em sua cinematografia não se dão, portanto, nas polaridades.

(C) ETD-Educação Temática Digital Campinas, SP $\quad$ v.19 $\quad$ n.2 $\quad$ p.418-436 abr./jun. 2017 
Durante o período em que esteve na escola de Belas Artes do Rio de Janeiro, apesar de haver recebido uma educação, cujos fundamentos eurocêntricos eram unívocos, a construção de seus conhecimentos já se materializava numa relação em que dialogavam duas vertentes, isto é, a formação eurocentrada formal e os conhecimentos de seu devir negro, ainda em processo de engendramento. Portanto, hoje, podemos dizer que o cinema de Bulbul se constitui por meio de dois novos olhares: um que não é ainda o ideal almejado pela ideia da liberdade sonhada, e outro que não mais reflete este "aqui agora" de total aprisionamento.

Walter Mignolo, em "Histórias Locais/ Projetos Globais: colonialidade, saberes subalternos e pensamento liminar",nos incita a pensar em teorias transculturadas, aquelas recebidas de outros territórios, e a possibilidade de se conceber um pensamento que rompe fronteiras. As reflexões do semiótico argentino apresentam teorias itinerantes e sugerem o que se pode fazer com elas quando entram em contato com a diferença colonial, ou seja, com os povos que foram subjugados culturalmente, e são sempre tratados como se tivessem que receber a "verdadeira cultura", aquela proveniente do Velho Mundo. Mignolo apresenta três possibilidades para resolver tal impasse: a primeira é a de que as teorias apresentadas às culturas subalternizadas podem propor a sua civilização e modernização. A segunda hipótese seria a de as culturas subjugadas negarem completamente tais teorias e de fecharem-se contra o estrangeiro. Por fim, as culturas que historicamente foram colonizadas poderem refletir e problematizar essa intersecção entreos seus conhecimentos e aqueles que são estrangeiros e, então, produzir uma epistemologia que não seja nem a do viajante e nem a do residente. (MIGNOLO, 2003)

Acreditamos que o importante na construção imagética do cinema negro em Zózimo é o "entre", e que se efetiva nessa terceira hipótese de Mignolo, que sincretiza e que se permite entrar em contato com outros conhecimentos com intuito de voltar-se para si mesmo, neste caso, à sua negritude, para daí construir outro pensamento que não é nem o do lugar determinado pelos estereótipos nem a concepção de uma cultura concebida pelo colonizador.A radicalidade desse pensamento político permitiu a criação de uma nova estética que consegue expressar seus pensamentos, não somente por uma convicção ideológica, mas dando voz e protagonismo àqueles que,no contexto histórico e sociológico, em sua maioria, até então haviam sido interpretados pelo Outro.

Entre a causa política e a criação de novas estéticas raciais, o cinema de Zózimo já então rompia com os estereótipos, para ir em busca da: 
[...] ideia arquipolítica do partido, isto é, a ideia de uma inteligência política que concentra as condições essenciais de transformação, e a ideia da virtualidade metapolítica da subjetividade política global, a ideia da virtualidade nos modos de experiência sensíveis e inovadores de antecipação da comunidade porvir (RANCIÉRE, 2009, p.44).

O pensamento de Rancière nos ajuda a entender que a perspectiva desse cineasta, entre o posicionamento político e a metapolítica da subjetividade, fundamentada na criatividade, evidencia a proposta de uma construção da estética racial que ainda está por acontecer. Apesar de, a princípio, Bulbul querer conscientizar a população negra, sua produção não se restringe ao pensamento desse grupamento sociorracial. A comunidade que está porvir relaciona tanto negros como não negros para o vislumbre de outras estéticas que se estabelecem também a partir do olhar do outro. Por isso, para tal, era urgente, na cinematografia de Bulbul, a evidência dos corpos, das vozes e dos conhecimentos das negritudes que historicamente foram, na sua formação, determinadas e conceituadas pelo olhar eurocêntrico.

\section{CINEMA, NEGRITUDES E CURRÍCULO: REPENSANDO A FORMAÇÃO DOCENTE}

\footnotetext{
“... a gente forçava o professor, porque já estávamos mais adiantados do que ele estava imaginando. A gente ficava inventando currículo de trabalho, de estudo" (Zózimo Bulbul)
}

Analisar a trajetória de vida e obra de Zózimo coloca-nos um desafio enquanto formadores de professores e suscita a pergunta: Qual o espaço para a construção de novas imagens dos negros em nossas aulas, grupos de pesquisa e eventos acadêmicos?

Acreditamos que existem múltiplas maneiras de pensar, produzir e constituir os saberes e os conhecimentos desenvolvidos historicamente por essa população. $O$ subtítulo que abre essa seção marca essa intencionalidade. A própria cinematografia de Zózimo nos convida a repensar os estereótipos ea colocar no plural a possibilidade de múltiplas formas de construção das negritudes. No entanto, as negritudes tentam se construir entre dois conhecimentos que estão no singular, porque, culturalmente,estão assim institucionalizados: o cinema e o currículo escolar.

A invisibilidade do negro na cinematografia brasileira para além dos estereótipos e, ao mesmo tempo, a rasa problematização das questões étnicas e raciais no currículo escolar são reflexos daquilo que se considerou válido, ou não, no conhecimento cultural da sociedade brasileira. Ultrapassar essa distorção entre os saberes que detêm mais valor do

\section{(C) ETD-Educação Temática Digital Campinas, SP $\quad$ v.19 $\quad$ n.2 $\quad$ p.418-436 abr./jun. 2017}


que outros é a possibilidade de compreender as possíveis relações entre cinema, negritudes e currículo. Como nos lembra Moreira: "Talvez se faça conveniente aprender conhecimentos estranhos ao campo da Pedagogia e do currículo, o que acarreta o engajamento de novos paradoxos" (2005, p.45).

A tríade Cinema, Negritudes e Currículo cada vez mais vem se relacionando pelas próprias políticas que,nos últimos tempos, convocam a escola para que leve em consideração novos conhecimentos. Dessa forma, quando argumentamos sobre a importância que o cinema confere ao currículo, lembramos que há dois anos foi promulgada a Lei n. 13.006/2014, de autoria do Senador Cristóvão Buarque, que determina a exibição de duas horas mensais de filmes nacionais como componente curricular nas escolas públicas do país. Assim, um dos principais questionamentos com relação a essa Lei se refere aos filmes que serão exibidos. Entendendo o impacto dessa legislação no currículo escolar, temos a oportunidade de questionar se o currículo, reformulado constantemente por decretos, abre possibilidades de incentivar novas produções que considerem as diversidades, as pluralidades etnorraciais, e que permitam aos professores e alunos, assim como fez o cineasta Zózimo Bulbul, inventarem currículos autônomos.

Anterior à Lei n. 13.006/2014, há a Lei n. 10.639/2003, que promulga as diretrizes curriculares para a educação das Relações Étnico-Raciais e para o Ensino de História e Cultura Afro-Brasileira e Africana. Esse documento também apresenta uma forte perspectiva de incentivo às diversidades étnicas e raciais, que historicamente se efetivaram através da música e da dança, como um modo de produção das imagens enquanto conhecimento da sociedade negra.

Diante das constantes intervenções da legislaçãono currículo da educação brasileira, torna-se cada vez mais importante repensar uma nova formação docente em que se problematize a diversidade do conhecimento, principalmente daqueles que não são parte integral dos sistemas escolares institucionalizados. Assim, como Zózimo questionou a escola e sua funcionalidade, bem como os conhecimentos nela considerados os mais válidos social e culturalmente, cabe a nós que estamos formando futuros professores com constante diálogo com o cinema, pensar de que forma essa arte permite aos licenciandos apropriarem-se de experiências estéticas ao se considerar as questões da negritude em diálogo com outras formas de conceber, produzir e compartilhar conhecimento.

No caso dos negros, que em número cada vez maior estão ingressando nos cursos de licenciatura, poderem refletir sobre a possibilidade de eles se visualizarem e de evidenciarem novas estéticas sobre sua etnia. No caso dos licenciandos não negros, que essas produções possam levar à compreensão de novas formas de se entenderem enquanto

\section{(C) ETD-Educação Temática Digital Campinas, SP v.19 n.2 p.418-436 abr./jun. 2017}


sujeitos sociais. Afinal, somente temos a possibilidade de nos compreendermos inseridos cultural, política e historicamente na relação com os outros sujeitos, mas de modo que haja aí a possibilidade de múltiplas vozes em diálogo.

O cinema de Bulbul inter-relaciona sujeitos, saberes e conhecimentos de forma tão indissociável que nos remete às informações multi e interculturais em que não importa se os termos "saberes" e "conhecimentos" são sinônimos ou se têm alidiferentes significados;mais importante é não os hierarquizar. Assim, o principal objetivo da interculturalidade é o de "estimular o diálogo entre os diferentes saberes e conhecimentos, e trabalhar a tensão entre universalismo e relativismo no plano epistemológico, assumindo os conflitos que emergem deste debate" (CANDAU, 2012, p.245).

O cineasta negro carioca nos desloca para outra ótica, em que é preciso reelaborar os próprios conhecimentos inculcados nas construções e idealizações sobre os negros no Brasil. Nesse caso, estamos diante de uma interculturalidade que almeja uma nova epistemologia, que rompe com as ideias de inserção ou valorização, tão comumente utilizadas quando se projetam as temáticas étnico-raciais na escola e na formação docente. Essa interculturalidade se consolida por conhecimentos que devem emergir de espaços epistêmicos dos povos negros e que, inclusive, sejam capazes de ampliar até mesmo as próprias perspectivas eurocêntricas.

Candau e Oliveira (2010) questionam como uma educação não eurocentrada pode se efetivar em uma formação docente que ainda enfoca epistemologicamente o eurocentrismo. Os autores acreditam que esse impasse epistemológico se efetiva pela provocação que os movimentos negros têm feito há bastante tempo por meio de uma desobediência epistêmica na dinâmica pela elaboração de políticas pautadas por suas próprias mobilizações. No mesmo caminho, Carla Beatriz Meinerz (2017), ao problematizar o ensino de História por meio da interculturalidade nas relações etnorraciais, compreende que os conhecimentos produzidos por intelectuais negros permitirão diferentes formas de pensar e agir como educadores e pesquisadores.

O cinema de Zózimo apresenta uma nova epistemologia que, ao colocar o negro em todas as suas potencialidades de visibilidade pela lente da câmera,ela já conduz para conhecimentos questionados pelas teorias entre currículo e interculturalidade. Acreditamos que,por parte de Zózimo, o resgate da ancestralidade por meio das corporeidades na constituição das sociedades negras em sua cinematografia já nos direciona para novos conhecimentos. As corporeidades não são apenas a estrutura orgânica, mas são formas de resistências que as populações negras encontraram para perpetuar tanto sua memória quanto sua oralidade e sua religiosidade. Como nos lembra Walter Mignolo (2003, p.256),

\section{(C) ETD-Educação Temática Digital Campinas, SP v.19 n.2 p.418-436 abr./jun. 2017}


"[...] as teorias itinerantes [...] não podem evitar as marcas inscritas em seus corpos pela colonialidade do poder que exige reflexão no e sobre o sistema mundial colonial moderno".

Ao contrário do que se concebeu na perspectiva eurocêntrica em que os conhecimentos impostos foram utilizados para reproduzir estereótipos sobre os corpos negros por meio de uma compulsiva racialização, Zózimo decalca em sua cinematografia que a constituição das negritudes está pautada em corporeidades, em que, apesar de histórias de opressão e possibilidades de aniquilação, ela se evidencia por uma re-existência entre as culturas africanas e aquelas que lhes foram impostas a partir de uma ideia de verdade.

Na relação com o outro, a oportunidade de valorização de novos conhecimentos produzidos pelos sujeitos vai gerar outras formas de conceber sua existência, sem necessariamente considerar uma cultura superior à outra. A pesquisadora Nilma Lino Gomes problematiza as possibilidades de hibridizações entre paradigmas, inseridos nas relações étnico-raciais, que não se restringem às disciplinas previamente determinadas para o ingresso no sistema escolar. Assim, para ela, as relações étnico-raciais indicam que:

\begin{abstract}
Um paradigma que compreende que não há hierarquias entre conhecimentos, saberes e culturas, mas, sim, uma história de dominação, exploração, e colonização que deu origem a um processo de hierarquização de conhecimentos, culturas e povos. Processo esse que ainda precisa ser rompido e superado e que se dá em um contexto tenso de choque entre paradigmas no qual algumas culturas e formas de conhecer o mundo se tornaram dominantes em detrimento de outras por meio de formas explícitas e simbólicas de força e violência. Tal processo resultou na hegemonia de um conhecimento em detrimento de outro e a instauração de um imaginário que vê de forma hierarquizada e inferior as culturas, povos e grupos étnico-raciais que estão fora do paradigma considerado civilizado e culto, a saber, o eixo do Ocidente, ou o Norte colonial (GOMES, 2012, p.102).
\end{abstract}

O pensamento de Gomes corrobora nossas argumentações para pensar o cinema negro de Zózimo Bulbul numa perspectiva em que muitos paradigmas necessitam ser rompidos. Portanto, nesse sentido é que nós nos propomos a buscar entender essa quebra conceitual por meio da intencionalidade política, estética e poética,fazendo uma análise do primeiro filme curta-metragem dirigido, produzido e interpretado pelo cineasta Zózimo Bulbul, Alma no olho, de 1974. 


\section{ALGUMAS POSSIBILIDADES DE ANÁLISE DO FILME ALMA NO OLHO DE ZÓZIMO BULBUL}

Alma no olho (1973) foi a primeira e uma das principais obras cinematográficas produzida, dirigida e interpretada por Zózimo Bulbul. Foi premiado na VI Jornada de CurtaMetragem de Salvador, Bahia, em 1977, e recebeu o Prêmio Embrafilme, com o Troféu Humberto Mauro.

O curta-metragem com duração de onze minutos e cinco segundos, realizado em preto e branco, apresenta Zózimo contando a trajetória do negro representando várias personagens somente pela expressão corporal. A história busca o "entre" fundamentado nas ancestralidades africanas de sujeitos que nasciam livres e suas relações com o presente no qual essas etnias almejavam expressar novas escolhas e existências. O filme todo resulta de uma performáticamise en scènedo ator, por vezes nu e outras vezes vestido com roupas brancas, num lugar onde o chão e as paredes são brancos.

Destaca-se, assim, fortemente o contraste do preto da sua pele contra o fundo totalmente branco do espaço onde ele encena suas diversas personagens. Na apresentação do título vemos um plano desfocado escuro, com letras brancas em escrita cursiva dizendo ALMA NO OLHO. Aos poucos a câmera se afasta e gradualmente começamos a perceber que as letras ocultavam justamente seus olhos. Um enquadramento do rosto do ator, roteirista, montador, produtor e diretor do filme aparece nitidamente, junto com os créditos, tomando desde a testa até abaixo do nariz. Seus olhos olham para esquerda e direita e finalmente olham para a câmera, penetrantes, antecipando no espectador certa dureza, como uma dívida a ser cobrada, um incômodo. Novamente, volta a explorar com seus olhos em todos os ângulos e um corte passa para a imagem inferior do rosto, desde o nariz até o queixo, quando anuncia que é uma obra dedicada a John Coltrane. ${ }^{3}$

O enquadramento foca seu sorriso que vira gargalhada, e a câmera parece mergulhar na sua garganta, deixando entrever no riso o movimento da língua e de todo o aparelho fonador. Porém, trata-se de uma imagem sem som. Apenas imaginamos essa gargalhada. Logo um corte abre para um plano oblíquo e depois lateral do seu rosto. A gargalhada dá lugar a um gesto com a boca bem aberta. Os músculos do perfil do rosto se movem pela ação da mandíbula articulada. Poderíamos dizer, que essa primeira personagem interpretada por Bulbul é a de um homem que se reconhece a partir de seu corpo. Entendemos que a personagem está nascendo e se deixa vir à existência. A câmera se detém numa orelha, no perfil do ombro e no pescoço. Corta para um plano do rosto que

\footnotetext{
3 John Coltrane (1926-1967), foi um prestigioso saxofonista negro norte-americano, dos mais cultuados no universo musical do jazz, com quem Zózimo Bulbul manteve uma relação de amizade e profunda admiração.
}

\section{(C) ETD-Educação Temática Digital Campinas, SP v.19 n.2 p.418-436 abr./jun. 2017}


vai ser interrompido pelo movimento das mãos cruzadas na frente, e ele sorri. Os detalhes dos primeiros planos deixam evidente a pretensão de levar o público a reconhecer essa personagem, já que é pelo rosto que sefaz a identificação dos sujeitos.

Em seguida, dois planos mostram dois pontos de vista bem próximos, um da axila e parte do rosto e outro que acompanha o suor que escorre de uma de suas axilas. As imagens provocam. O suor é uma substância que vem do interior do organismo. Como o próprio título indica, é a alma que precisa ser impregnada nos olhos daqueles que veem. Uma sequência de planos que começa tomando o lado direito das costas, ombro e rosto, continua pelo peito, axila, uma mão que se abre lentamente do lado do peito, cujos pelos se confundem imediatamente com ospelos do púbis e, a seguir, suas nádegas. Um corte nos leva a ver seus pés em movimento, quase ensaiando passos, mas sem sair do lugar. 0 ritmo da marcha começa a aumentar, juntamente com a música de Coltrane ao fundo, enquanto a câmera vai subindo mostrando o lado esquerdo levemente por trás. Dança ou corrida? 0 movimento indica liberdade, expressão aberta, alegria.

Apesar dos poucos segundos para cada parte mostrada do corpo da personagem, o espectador vivencia certo estranhamento com a exposição dessa nudez, dessas imagens sem fala, que aumentam a centralidade da imagem negra no fundo branco. Como fizera Hitchcock em Psicose, tentando driblar o comitê de ética hollywoodiano sobre a proibição de mostrar partes do corpo em plano-sequência, Zózimo constrói uma imagem do corpo nu que tem mais força do que qualquer imagem explícita de corpo inteiro. Imaginamos que essas primeiras imagens trazem a questão central do filme,isto é, colocar o corpo e sua cor no centro do debate. Invisibilizar qualquer outros imageme som, que não destaquem o principal, i.e., a negritude de um corpo vivo, forte, belo, livre e dono de si mesmo.

Uma nova sucessão de planos apresenta a segunda personagem interpretada por Zózimo, que é a de um homem que traja vestimentas de uma tribo africana. Imagens da primeira personagem vão contrapondo-se às da segunda. Essa ideia demonstra uma mudança desse homem que nasceu livre e corria por seu território e que, em um segundo momento, já se reconhece como alguém que detém poder e prestígio. A segunda personagem evidencia que a África também teve reinados. Nesse momento do filme, há uma alternância entre a primeira e a segunda personagem, que continua a reconhecer suas origens a partir da expressão corporal, tocando-se, sentindo-se a si próprio e acrescentando o figurino de uma realeza africana. A alegria da personagem que dança bem-vestida é alternada gradualmente por planos de close do rosto que olha para a câmera com uma expressão de suspeita. Dessa forma, a personagem sai de cena e a câmera fixa a tela, toda branca. Em seguida, a personagem aparece andando para trás com uma expressão de estranhamento ao começar a dar-se conta de todo o cenário em branco a sua volta.

\section{(C) ETD-Educação Temática Digital Campinas, SP v.19 n.2 p.418-436 abr./jun. 2017}


Então, uma imagem em plongée $e^{4}$ mostra a personagem deitada no chão com os braços abertos, evocando a imagem do crucifixo; em seguida olha, procurando saída, rota de fuga, e começa a andar, como tentando fugir para o lado esquerdo do quadro. Um corte passa para um novo plongée, onde se vê a personagem em posição fetal, de frente, ocultando o rosto com os próprios braços - com braceletes brancos - e, ao abri-los, descobrimos que se trata de uma corrente, branca. Ao tocar a superfície do território completamente branco ao qual está preso, ele faz diversos movimentos com os braços tentando inutilmente fugir desse lugar, soltar-se dos braceletes, revelando sua impotência. Toca o rosto e busca vias de escape com as pernas girando sobre o próprio eixo em círculos, enquanto alguns cortes com closes do rosto refletem dor e desespero.

A partir do sétimo minuto do filme, o som começa a tomar parte da cena. Trata-se de sons dissonantes que acrescentam o sentimento de um incômodo que as imagens provocam. Um ruído mais forte sobressai quatro vezes lembrando o apito de um navio. Esse som, com a agonia da personagem presa por uma corrente,compõe a ideia de opressão depois deter sido retirada da sua terra livre e levadapara outra realidade,em referência aos muitos negros que foram retirados da terra natal e jogados nos porões dos navios negreiros.

O protagonista negro, que antes se reconhecia em sua ancestralidade e tinha o domínio sobre sua cultura e sua vida, agora está preso. As correntes e a bermuda branca reiteram, pela cor desses objetos, o processo de dominação sobre os povos negros. A agonia do prisioneiro se transforma em loucura a partir do momento em que a personagem se conforma com a condição de opressão. É possível observar que a personagem traz pendurada ao pescoço uma espécie de amuleto, aparentandoo dente de um animal africano, que simboliza uma memória presente em meio aos processos opressivos.

Com as alterações dos planos, do figurino e dos movimentos, somos levados a ver uma sucessão de situações dos modos de existência mais estereotipados do negro em sociedade. Do processo escravocrata aos dias atuais, as personagens interpretadas por Zózimo reiteram as posições às quais os negros continuam aprisionados: o lavrador, que produz os alimentos que serão consumidos por toda a sociedade; o jogador de futebol, que representa uma pequena parcela de homens negros que se destacam pelas habilidades corporais através de gingas e dribles. O sambista que demonstra toda sua força, beleza e garra durante as festividades de Momo; o pugilista que perpetua a ideia da capacidade para

\footnotetext{
${ }^{4}$ Plongée = termo francês que, em português, significa "mergulho" e que, em linguagem cinematográfica, consiste em filmar um ator de cima para baixo. Tal técnica apresenta uma ideia de inferioridade da personagem em relação ao enquadramento total do plano-sequência.
}

(C) ETD-Educação Temática Digital Campinas, SP v.19 n.2 p.418-436 abr./jun. 2017 
atingir o adversário; o ladrão que, de modo sorrateiro, esconde o produto furtado; o pedinte que insiste em incomodar os transeuntes nos grandes centros urbanos.

As personagens mencionadas anteriormente fazem performances que,até hoje,representam seus corpos em movimento,limitados às especificidades de uma atividade, ao contrário das primeiras personagens que não estavam presas a uma denominação social e que conseguiam demonstrar de forma mais plena seus corpos em consonância com sua liberdade.

A loucura segue perturbando a mente da personagem que na atualidade continua escrava das elaborações dos outros. E mesmo quando existe possibilidade de ascensão social, representada em outro plano por um violonista e um intelectual, as correntes continuam a aprisionar a personagem e reiteram o caráter da, ainda hoje, limitação de uma cultura que considera que não há possibilidade de criar imagens a partir do que as populações negras idealizam. Não há terno branco que desfaça os braceletes. Eles acompanham a personagem o tempo inteiro, e assim, ao tentar desvencilhar-se deles, não consegue; nu ou vestido, qualquer tentativa é vã.

Uma possível leitura seria a de imaginar que a personagem entende que só há uma possibilidade de voltar a si mesma. Aos poucos, a personagem vai abandonando cada uma das peças da vestimenta branca: paletó, camisa, calça, bermuda, sapato. Aliás, a bermuda branca é substituída por uma espécie de tanga preta. De algum modo, ele volta ao que era, somente com o seu corpo, livre como nasceu. Regressa à primeira personagem do filme, que caminha em direção à câmera, levanta os braços e arrebenta as correntes. Olha novamente para a câmera, agora sorridente e, ao se aproximar, a própria figura, e inclusive as correntes, convertem-se em silhuetas contra o fundo branco e, então, curiosamente, ficam pretas. Então, o corpo negro toma conta da tela e aparecem os créditos.

\section{DO CINEMA NEGRO DE ZÓZIMO BULBUL À FORMAÇÃO DE PROFESSORES}

Analisar um filme é sempre um risco. Como qualquer análise ela é marcada por incompletudes do nosso próprio ponto de vista, conhecimentos, experiências e ignorâncias que convergem em uma dentre tantas outras leituras possíveis.

Optamos por uma descrição detalhada da linguagem, por acreditarmos que a proposta de Zózimo é didática, e ao mesmo tempo inovadora, a partir da ideia das imagens das personagens que a todo o momento vivem o conflito de uma possibilidade de ser entre o almejado e o que a realidade impõe. Isto é, a montagem de planos curtos alternando as imagens da personagem inicial, com as diferentes personagens propostas, refletem o

\section{(C) ETD-Educação Temática Digital Campinas, SP v.19 n.2 $\quad$ p.418-436 abr./jun. 2017}


conflito de uma liberdade ainda condicionada pelas circunstancias de trabalho, pela (in)disposição social para com os diversos estereótipos que, piores do que correntes, escravizam olhares e modos de relação com os cidadãos negros.

Nesse sentido, ao analisarmos esse filme, temos a sensação de ver imagens entre realidade e ficção. Em alguma medida, podemos encontrar nesse gesto o que Rancière chama de "revolução estética". Zózimo cria o que o filósofo francês conceituou como "a indefinição das fronteiras entre razão dos fatos e a razão das ficções e o novo modo de racionalidade da história e de sua ciência" (RANCIÈRE, 2009, p.54).

Assim, a relação entre escravidão e liberdade é construída não somente pela belíssima interpretação de Zózimo Bulbul, mas também pela visão dos espectadores, já que o texto fílmico não se constrói pela linguagem oral, exigindo daquele que o assiste uma maior atenção e uma interpretação mais autônoma do conjunto da obra.

Essa ideia se associa ao que Rancière já abordava em o "espectador emancipado":

Quanto à emancipação, essa coisa começa quando se põe em questão a oposição entre olhar e agir, quando se compreende que as evidências que assim estruturam as relações do dizer, do ver e do fazer pertencem elas próprias à estrutura da dominação e da sujeição. A emancipação começa quando se compreende que olhar é também uma ação que confirma ou transforma essa distribuição das posições. O espectador também age, como o aluno ou o cientista. Observa, seleciona, compara, interpreta (RANCIÈRE, 2010, p.22).

ComAlma no olho, o espectador consegue trazer para si interpretações que deixam em evidência uma relação que lhe permite entender o texto por situaçõesda realidade que já foram ou vivenciadas ou imaginadas. Como postula Rancière: "Liga o que vê com muitas outras coisas que viu noutros espaços cênicos e noutro gênero de lugares" (2010, p.22).

Nesse vetor,Alma no olho motiva o espectador a pensar e a construir suas próprias imagens a partir de um gesto muito simples: olhar e imaginar que as escolhas do diretor poderiam ter sido outras. Zózimo interpreta personagens que olham constantemente para a câmera. Para entender a intencionalidade de novas imagens, primeiro é preciso olhar fundo nos olhos. É um pequeno ato que exige vontade, mas causa estranhamento, inibições, rompimento com certas limitações. É um processo emancipatório que começa pelo olhar, para assim ser possível a produção de imagens das negritudes que não mais incomodarão.

A nós que estamos em processos de formação docente, que reconhecemos a necessidade de trazer as questões étnicas e raciais para o centro do cenário formativo, consideramos que este curta constitui uma experiência estética com alta potencialidade para afetar os futuros professores para além dos conhecimentos sobre a temática.

\section{(C) ETD-Educação Temática Digital Campinas, SP v.19 n.2 p.418-436 abr./jun. 2017}


Principalmente a partir das imagens, Zózimo, no filme Alma no olho, nos incita a trazer para o cerne do conhecimento, para além das imagens desgastadas do negro na cultura e na sociedade, cenas que nos afetam, provocam, e que podemos imaginar de outras formas. Isso não significa que o passado de opressão e de estigma deva ser esquecido. Ao contrário, queremos propor uma passagem do esquecimento para o ressignificado.

O primeiro conhecimento nessa perspectiva emancipatória é que Zózimo motiva o espectador a construir as negritudes pelos objetos, os quais ele critica, para produzir novas estéticas. Zózimo cria, partindo das imagens e impressões do negro que a sociedade já havia construído. No entanto, o curta demonstra que o caráter criativo do cineasta permite que as personagens não somente representem uma ficção, mas que a imaginação também conduza outras realidades a partir de temas já debatidos na cinematografia brasileira: a liberdade, a escravidão e as novas formas de negociação para que o negro se mantenha em sociedade.

O segundo conhecimento que Zózimo coloca, para novas aprendizagens imagéticas do negro, é a relação de corporeidade como objeto propulsor de linguagens e significados. Essa questão torna-se evidente com a intencionalidade do autor ao recorrer somente à expressão corporal, sem utilização da linguagem verbal. Stuart Hall afirma que é necessário observar no repertório negro que o "estilo", que "os críticos culturais da corrente dominante muitas vezes acreditam ser uma simples casca, uma embalagem, o revestimento de açúcar na pílula" (HALL, 2003, p.342), é em si o próprio acontecimento.

Tanto as primeiras personagens, em seu estado de plena liberdade, quanto as últimas que se apresentam aprisionadas, são elaboradas com e pelos corpos. $O$ caráter produtivo das personagens do filme tem nas corporeidades o elo que relaciona o passado e o presente, a antiguidade e o contemporâneo. Assim, o corpo é o princípio da possibilidade para pensar as imagens, permitindo "uma nova 'partilha do sensível', na medida em que une num mesmo conceito os termos tradicionalmente opostos da atividade fabricante e da visibilidade" (RANCIÈRE, 2005, p. 67).

Nessa perspectiva, Hall não dissocia o ato de ser com os saberes que se fundamentam sob outros olhares. No caso da produção deAlma no olho, Zózimo constrói o conhecimento a partir do saber corpóreo. Assim como é representada nas primeiras cenas do filme,com o corpo em primeiro lugar, a personagem se reconhece, masse estranha quando tem esse mesmo corpo aprisionado e limitado.

A segunda observação feita pelo pensador jamaicano é sobre outras formas de registro da produção cultural dos povos das diásporas negras, para além da escrita, que

\section{(C) ETD- Educação Temática Digital Campinas, SP $\quad$ v.19 n.2 $\quad$ p. 418-436 abr./jun. 2017}


rompem com os domínios e significados culturais impostos, como a música. Essa analítica de Hall é compreendida quando abordamos as manifestações da cultura afro-brasileira que lutaram não somente para preservar suas origens, como também para também para reconstruir outras possibilidades de existência, seja nas práticas religiosas, seja nas culturais e educacionais. No curta-metragem de Zózimo, quando a primeira personagem se apropria de seu corpo, consegue expressar-se entre a liberdade e o processo de escravidão. $\mathrm{Na}$ dança, as personagens de Alma no olho relacionam passado e presente não de forma determinada por uma época, mas tentando ao mesmo tempo corresponder a um "sentido de comunidade". (RANCIÈRE, 2009)

Por último, Hall pede para se pensar "em como essas culturas têm usado o corpo como se ele fosse, e muitas vezes foi, o único capital cultural que tínhamos" (2003, p.342). Na reflexão da cultura afro-brasileira, entendemos esse capital cultural não como único em seu sentido limitador, mas com a compreensão de onde se colocam presentes todas as maneiras de se conceber os conhecimentos que nos fazem ser e estar em uma cultura. É no corpo, não apenas numa perspectiva orgânica, mas produtiva, em seu sentido pleno da relação com aspectos da naturalidade, do contato com o outro e como motor de transformação, é que se torna possível conceber formas de subjetividades e representações.

\section{CONSIDERAÇÕES FINAIS}

Pelo corpo que se efetiva entre a ficção e a realidade, Zózimo nos mostra múltiplas possibilidades de repensar a própria ideia de que o conhecimento não se elabora sem nossa relação com ele próprio. Assim, o curta-metragem Alma no olhopode nos permitir, a nós que elaboramos os processos da formação docente, promover questões até hoje bastante desvalorizadas e esquecidas: entender como podemos nos inserir enquanto sujeitos, que não somos meros reprodutores, mas constantes elaboradores daquilo que trazemos em nós. Assumir esse posicionamento e não nos curvarmos a uma ideia de aceitação dos conhecimentos impostos, mas sim de os entender em processo, ao mesmo tempo em que se reiteram necessidades contingentes de reelaborações que permaneçam atreladas aos desejos de uma memória que não deve ser esquecida.

Esse cineasta nos permite, com sua obra,que possamos provocar situações pedagógicas nas quais os filmes coloquem experiências estéticas que sejam simultaneamente políticas e éticas. Pensar na relação com a liberdade a partir da sociedade negra constitui um extremo de impossibilidades que nos convidam a pensar no próprio e limitado exercício da liberdade, altamente condicionado pela história e pela linguagem, pelas condições financeiras, morais, sociais, conjunturais.

\section{(C) ETD-Educação Temática Digital Campinas, SP v.19 n.2 p.418-436 abr./jun. 2017}


Voltando às formas como Zózimo começou a questionar a cultura afro-brasileira e as formas limitadas pelo racismo e o preconceito,ao questionar o currículo, o cineasta estava pensando no seu lugar enquanto criança negra em um espaço cujos conhecimentos eram válidos somente se estivessem de acordo com um modo de entender a produção cultural imposta pelo processo da colonização europeia, tida como verdadeira.

Assim, não basta somente escolher filmes que abordem as questões étnicas e/ouraciais, mas é preciso potencializar novas imagens que ultrapassem a ideia das liberdades contemporâneas aprisionadas, ou seja, daquelas que permitem a construção de imagens apenas de acordo com o que é possível, como os nossos olhos se acostumaram. 0 posicionamento político de Zózimo que dá voz às novas estéticas negras, coloca para nós, professores, uma nova forma de elaboração do conhecimento imagético que consiste:

[...] na produção de sujeitos que dão voz aos anônimos, a política própria da arte no regime estético consiste na elaboração do mundo sensível do anônimo, dos modos de isso e do eu, dos quais emergem mundos, o mundo próprio de cada nós político (RANCIÈRE, 2009, p.98).

Entendemos que o negro anônimo, este que precisamos trazer à tona, aproxima-se do cinema de Zózimo Bulbul na medida em que as imagens, antes ocultadas, questionam nossas singularidades.Nesse caráter relacional, compreendemos que o sujeito se torna audível e visível quando coloca essa corporeidade em ação para "fazer ver aquilo que não se via ou para passar a ouvir como palavra que discute o interesse comum aquilo que era ouvido somente como ruído do corpo" (RANCIÈRE, 2010, p. 90).

Se pelo corpo Zózimo potencializou grande parte dos saberes e conhecimentos do negro no curta-metragem Alma no olho, as questões étnicas e raciais ficam impressas em nós educadores, que, afetados pelas imagens, pelos sons, pelo fluxo das sequências de dor e impossibilidade, transpiramos junto com Zózimo a necessidade de esquecer que fomos constantemente minimizados mediante os estereótipos e, sim, visibilizar novos modos de ser e estar negro neste mundo.

\section{REFERÊNCIAS}

BRASIL. Lei n. 13.006, de 26 de junho de 2014. Estabelece a exibição de filmes de produção nacional que constituirá componente curricular integrada à proposta curricular da escola sendo a sua exibição obrigatória por no mínimo duas horas mensais. Diário Oficial da União, Brasília, DF: Presidência da República, 26 jun, 2014. 
BRASIL. Lei n. 10.639, de 09 de janeiro de 2003. Estabelece as diretrizes Curriculares Nacionais para a Educação das Relações Étnico-Raciais e para o Ensino de História e Cultura Afro-Brasileira e Africana. Diário Oficial da União, Brasília, DF: Presidência da República, 09 jan, 2003.

BULBUL, Zózimo [et al]. Zózimo Bulbul: uma alma carioca. Jefferson De (Organização de textos). Rio de Janeiro, RJ: Centro Afro Carioca de Cinema: Fundação Palmares, 2014. CANDAU, Vera. Diferenças culturais, interculturalidade e educação em Direitos Humanos.

Revista Educação e Sociedade, Campinas, SP, v. 33, n. 118, p.235-250, jan./mar., 2012. ISSN 0101-7330

CANDAU, Vera; OLIVEIRA, Luís Fernandes de. Pedagogia decolonial e Educação antirracista e intercultural no Brasil. Educação em Revista, Belo Horizonte, MG, v. 26, n. 01, p.15-40, jan./abr., 2010. ISSN 0102-4698.

FRESQUET, Adriana. Cinema e Educação: reflexões e experiências com professores e estudantes de educação básica, dentro e "fora" da escola. Belo Horizonte, MG: Autêntica, 2013.

GOMES, Nilma Lino. Relações étnico-raciais, educação e descolonização dos currículos. Revista Currículo sem Fronteiras, Belo Horizonte, MG, v. 12, n. 1, p.98-109, jan. /abr., 2012.

HALL, Stuart. Da diáspora: identidades e mediações culturais. Liv Sovik (Org.); Tradução de Adelaine La Guardia Resende et al. Belo Horizonte, MG: UFMG, 2003.

MIGNOLO, Walter. Histórias locais/ Projetos globais: colonialidade, saberes subalternos e pensamento liminar. Tradução de Solange Ribeiro de Oliveira. Belo Horizonte, MG: UFMG, 2003.

MEINERZ, Carla Beatriz. Ensino de História, Diálogo Intercultural e Relações Étnico-Raciais. Revista Educação \& Realidade, Porto Alegre, RS, v. 42, n. 1, p.59-77, jan./mar., 2017.

MOREIRA, Antônio Flávio Barbosa. O estranho em nossas escolas: desafios para o que se ensina e o que se aprende. In: GARCIA, Regina Leite; ZACCUR, Edwiges; GIAMBIAGI, Irene (Org.). Cotidiano: diálogos sobre diálogos. Rio de Janeiro, RJ: DP\&A, 2005, p.29-48.

RANCIÈRE, Jacques. O espectador emancipado. Tradução de José Miranda Justo. Lisboa: Orfeu Negro, 2010.

(c) ETD-Educação Temática Digital Campinas, SP v.19 $\quad$ n.2 $\quad$ p. 418-436 abr./jun. 2017 
RANCIÈRE, Jacques. A partilha do sensível: estética e política. Tradução de Mônica Costa Netto. São Paulo, SP: 34: EXO Experimental Org., 2009.

\section{FILME}

ALMA no olho. Zózimo Bulbul.Estúdio de Mixagem: Laboratório Imagem Líder Rio, Rio de Janeiro, RJ, 1973.1 filme curta-metragem (12 min.), 35 mm, P\&B.

'Revisão gramatical do texto sob a responsabilidade da equipe da revista ETD 